\title{
A retrospective study on the diagnosis of clostridial myonecrosis in ruminants in Brazil
}

\author{
Prhiscylla Sadanã Pires ${ }^{1}$ Roselene Ecco ${ }^{1}$ Rodrigo Otávio Silveira Silva ${ }^{{ }^{*}}$ \\ Marina Rios de Araújo ${ }^{1}$ Felipe Masiero Salvarani ${ }^{2}$ Luíz Guilherme Dias Heneine ${ }^{3}$ \\ Carlos Augusto de Oliveira Júnior ${ }^{1}$ Francisco Carlos Faria Lobato ${ }^{1}$
}

${ }^{1}$ Escola de Veterinária, Universidade Federal de Minas Gerais (UFMG), Avenida Antônio Carlos, 6627, 31270-901, Belo Horizonte, MG, Brasil. E-mail: rodrigo.otaviosilva@gmail.com. *Corresponding author.

${ }^{2}$ Instituto de Medicina Veterinária, Universidade Federal do Pará (UFPA), Castanhal, PA, Brasil.

${ }^{3}$ Fundação Ezequiel Dias (FUNED), Belo Horizonte, MG, Brasil.

ABSTRACT: A standardized immunochemistry method for the diagnosis of clostridial myonecrosis was applied to 38 formalized tissue samples from ruminants with clinical and post mortem history suggestive of blackleg or gas gangrene. The diagnosis of clostridial myonecrosis was confirmed in 37 out of 38 (97.4\%) samples tested. Clostridium chauvoei and Clostridium perfringens type A were the most common agents found alone, being detected in ten (26.3\%) and six (15.8\%) samples, respectively. The other cases showed an association of two or three clostridia, with $\boldsymbol{C}$. perfringens type A detected in 11 (29\%) cases. Based on the findings of the present study, polyvalent vaccines against clostridial infections of animals incorporating $C$. perfringens would be more adequate for preventative purposes in the endemic areas. Key words: gas gangrene, blackleg, malignant edema, cattle, sheep, immunohistochemistry.

Estudo retrospectivo sobre o diagnóstico de mionecroses clostridiais em ruminantes no Brasil

RESUMO: Imuno-istoquímica padronizada para avaliar o diagnóstico etiológico de mionecrose por agentes do gênero Clostridium foi utilizada em 38 tecidos formalizados de ruminantes com suspeita clínica e macroscópica, além de histopatologia compativel com carbúnculo sintomático ou gangrena gasosa. O diagnóstico de mionecrose foi confirmado em 37 das 38 (97,4\%) amostras avaliadas. Clostridium chauvoei e Clostridium perfringens tipo A foram os únicos agentes encontrados sozinhos, sendo detectados em dez (26,3\%) e seis (15,8\%) amostras, respectivamente. Os outros casos foram causados por combinações de dois ou mais agentes, sendo que $\boldsymbol{C}$. perfringens type A foi detectado em dez $(29,9 \%)$ dessas amostras. Baseado nos resultados obtidos, sugere-se que vacinas polivalentes contendo $C$. perfringens seriam mais adequadas para prevenção de mionecrose causada por clostrídios.

Palavras-chave: gangrena gasosa, carbúnculo sintomático, edema maligno, bovinos, ovinos, imuno-istoquímica.

\section{INTRODUCTION}

Clostridial myonecrosis comprise necrotizing soft tissue infections caused by one or more pathogenic clostridia, including Clostridium septicum, Clostridium chauvoei, Clostridium novyi type A, Clostridium perfringens type A, and Clostridium sordellii. This disease affects several species; however, it is more relevant in domestic ruminants and is responsible for marked economic losses (UZAL et al., 2003a; ODANI et al., 2009; ASSIS et al., 2010; GROSETH et al., 2011). Clostridial myonecrosis can also be divided into two diseases, blackleg and gas gangrene, according to its etiological agent and pathogenesis. Blackleg, caused exclusively by $\boldsymbol{C}$. chauvoei, affects cattle mostly between 6 and 18 months of age and is a nontraumatic (or endogenous) infection. Conversely, gas gangrene affects animals at any age and is characterized by exogenous infection. Gas gangrene starts with a traumatic lesion, commonly vaccination, parturition, neutering, docking and blood extraction, followed by the contamination of the wounds by one or more of the histotoxic clostridia, including $\boldsymbol{C}$. chauvoei (LOBATO et al., 2013).

Laboratory diagnosis of clostridial myonecrosis is commonly based on a fluorescent antibody test (FAT) or isolation of the etiological agent. Both tests are applicable only in fresh tissues stored under refrigeration or frozen samples to avoid 
multiplication of saprophytic clostridia. This limitation is relevant in a continental-sized country such as Brazil, where farms are commonly far from research and diagnosis centers. Immunohistochemistry (IHC) could be an alternative, allowing the detection of infectious agents in situ using specific antibodies and marker molecules (ASSIS et al., 2010). Use of formalin-fixed tissues makes the collection, storage and shipment of the specimens easier and also reduces the interference of autolysis and growth of saprophytic clostridia that could interfere in the diagnosis. In addition, IHC also allows retrospective studies, which could help in understanding the epidemiology of the disease (UZAL et al., 2003b; RAMOS-VARA et al., 2008).

Despite the known importance of gas gangrene and blackleg in animals in Brazil, most diagnoses are based only on clinical signs or gross lesions. Specimens are rarely submitted to the laboratory for diagnosis and confirmation (LOBATO et al., 2013). In addition, the literature is mostly based on case descriptions, commonly atypical cases or outbreak reports (LIMA et al., 2006; CASAGRANDE et al., 2015). Thus, the frequency of the clostridia species involved in regular myonecrosis is largely unknown. The aim of this study was to apply a standardized immunochemistry test for the diagnosis of clostridial myonecrosis in 38 formalized tissue samples from ruminants with clinical and post mortem history of blackleg or gas gangrene.

\section{MATERIALS AND METHODS}

A total of 38 formalin-fixed tissues were included in the present study, including 34 bovine and 4 ovine samples. These tissues were sent from 34 different farms located in southeast, northeast and center-west Brazil. These animals died between 2000 and 2015 with clinical and pathological findings consistent with clostridial myonecrosis. The clinical history of each animal was recovered and analyzed. Histological sections were prepared and re-examined to evaluate the degree of autolysis (absent, mild to moderate or marked).

Tissue sections (skeletal and cardiac muscles) were submitted to the laboratory for IHC (PIRES et al., 2012). Briefly, the histological sections were treated with $3 \%$ hydrogen peroxide and $10 \%$ bovine serum albumin and placed into a humid chamber at $37^{\circ} \mathrm{C}$ for 30 and 15 minutes, respectively. The sections were then covered and incubated with the primary antibody at $37^{\circ} \mathrm{C}$ for 40 minutes. Dilutions of primary antibodies were
1:3000, 1:200, 1:30, 1:200 and 1:400 for C. septicum, C. chauvoei, $\boldsymbol{C}$. novyi type A, $\boldsymbol{C}$. perfringens type A and $\boldsymbol{C}$. sordellii, respectively. Then, the slides were incubated with biotinylated antibody (Dako, USA) and exposed to a streptavidin-peroxidase conjugate (Dako, USA). These steps were interspersed with three washes with phosphate buffered saline (1M PBS, pH 7.4) for five minutes each, and DAB (3.3-diaminobenzidine tetrahydrochloride, Dako, USA) was used as a chromogen. Tissue sections were counter stained with Harris hematoxylin, dehydrated with graded ethanol, cleared in xylene, and cover slipped with Permount. Control tissues, obtained as described by PIRES et al. (2012), were included in all tests.

\section{RESULTS AND DISCUSSION}

From the 38 tissues included in the present report, $34(89.5 \%)$ were from bovines and 4 from sheep (10.5\%), aged 7-36 and 5-18 months, respectively, with a mean age of 13 months and standard deviation of 7.1 months. The mean age reported in the present study was expected, as blackleg and gas gangrene commonly affect ruminants younger than 18 months old (LIMA et al., 2006; ASSIS et al., 2010; UZAL et al., 2016).

Considering the 34 farms included in this study, 27 (79.4\%) experienced individual clinical cases, while the remaining seven farms (20.6\%) showed outbreaks with more than one animal affected. In four of these outbreaks, only one animal was sampled, two farms submitted two animals and one farm collected tissues from three animals from the same outbreak. Among the 38 tissues evaluated, 35 (92.1\%) were from skeletal muscles mostly from the limbs or neck, and three (7.9\%) were from myocardial muscle. A history of sudden death of apparently healthy animals was reported in nine $(23.7 \%)$ out of the 38 cases, including all three of the samples with a presumptive diagnosis of clostridial myocarditis.

Initial histopathologic re-evaluation revealed the absence of autolysis in most of the samples $(28 / 38=73.7 \%)$. Mild and moderate autolytic changes were observed in $21 \%(8 / 38)$ and $5.3 \%(2 / 38)$ of the cases, respectively. Absence of severe autolytic changes suggested that the collection and storage of these tissues were conducted correctly. Thus, growth of saprophytic and carcass invaders was not a concern in these cases, and the detection of histotoxic clostridia was made only in the lesion area. In fact, the reduction of autolysis and growth of saprophytic 
clostridia proportionated by formalin-fixed tissues increased the positive predictive value of etiological diagnosis (RAMOS-VARA et al., 2008). According to UZAL et al. (2016), presence of changes consistent with myonecrosis, in the absence of marked autolytic alterations, and associated with the bacteria in situ indicated that the disease occurred and allowed the definitive diagnosis of clostridial myonecrosis.

Clostridial myonecrosis was confirmed by IHC in 37 out of $38(97.4 \%)$ samples tested. Interestingly, the negative sample was one of the two detected with mild autolytic changes. $\boldsymbol{C}$. chauvoei and $\boldsymbol{C}$. perfringens type A were the most common agents reported as a single infection; these agents were detected in ten $(26.3 \%)$ and six $(15.8 \%)$ samples, respectively (Table 1). $\boldsymbol{C}$. septicum and $\boldsymbol{C}$. novyi were also detected as single infections in one case each $(2.6 \%)$. In both single and co-infection, $\boldsymbol{C}$. chauvoei was the most frequently detected agent, as it was reported in 26 (68.4\%) samples, followed by $\boldsymbol{C}$. perfringens type A (17 sample - 44.7\%), C. septicum (12 samples - 31.6\%), C. sordellii (four samples - 10.5\%) and C. novyi type A (four samples - 10.5\%) (Table 2).

The high frequency of $\boldsymbol{C}$. chauvoei in the myonecrosis of ruminants is expected and corroborates previous studies (WILLIAMS, 1977; ASSIS et al., 2010; UZAL et al., 2016). This agent is responsible for blackleg, a very common disease in cattle that occurs also in large outbreaks (LOBATO et al., 2013). Notably, in the cases where only $\boldsymbol{C}$. chauvoei was detected, the owners reported that animals with good nutrition and in good health were affected, which also corroborates previous studies (WILLIAMS, 1977; ASSIS et al., 2010; GROSETH et al., 2011; CASAGRANDE et al., 2015).

Two samples from myocardial muscle were positive for $\boldsymbol{C}$. chauvoei alone, confirming the diagnosis of clostridial myocarditis, a manifestation of blackleg that commonly leads to sudden death in bovines (UZAL et al., 2003a; CASAGRANDE et al., 2015). In fact, among the 28 cases evaluated, eight $(28.6 \%)$ reported sudden death of apparently healthy animals, including the three diagnosed with clostridial myocarditis. In light of this result, blackleg and gas gangrene should be always considered in the differential diagnosis of sudden death in cattle, mostly in animals younger than 24 months (UZAL et al., 2016). In addition to the importance of $\boldsymbol{C}$. chauvoei as the etiological agent of blackleg, this agent is also eventually responsible for gas gangrene in ruminants, so the high frequency reported in the present study is not surprising. This agent is also involved in malignant edema in other domestic and wild animals (NAGANO et al., 2008; HOGG et al., 2009; MACÊDO et al., 2012).

Conversely, the high frequency of $\boldsymbol{C}$. perfringens type $\mathrm{A}$ reported in the present study (as single or in co-infection with other species) is definitely unexpected and contrasts previously with reports of a very low frequency of this agent (CORREA et al.. 1980; UZAL et al., 2016). Very few

Table 1 - Etiologic diagnosis by immunohistochemistry of 38 samples from bovines and ovines with clinical and pathological data of clostridial myonecrosis (2000-2015).

\begin{tabular}{|c|c|}
\hline C. chauvoei & $10(26.3)$ \\
\hline C. perfringens type $\mathrm{A}$ & $6(15.8)$ \\
\hline C. septicum, C. chauvoei and $C$. perfringens type A & $4(10.5)$ \\
\hline C. chauvoei and $C$. perfringens type A & $3(7.9)$ \\
\hline C. septicum and C. chauvoei & $3(7.9)$ \\
\hline C. septicum, C. chauvoei and $C$. sordellii & $2(5.3)$ \\
\hline C. chauvoei and C. Sordellii & $2(5.3)$ \\
\hline C. septicum and $C$. perfringens type A & $2(5.3)$ \\
\hline C. septicum & $1(2.6)$ \\
\hline C. novyi & $1(2.6)$ \\
\hline C. septicum, $C$. novyi type A and $C$. perfringens type A & $1(2.6)$ \\
\hline C. chauvoei, $\boldsymbol{C}$. novyi type A and $\boldsymbol{C}$. perfringens type A & $1(2.6)$ \\
\hline C. chauvoei and $C$. novyi type A & $1(2.6)$ \\
\hline Negative & $1(2.6)$ \\
\hline Total & $38(100)$ \\
\hline
\end{tabular}


Table 2 - Frequency of each histotoxic clostridia in 37 confirmed cases of myonecrosis from bovines and ovines in Brazil (2000-2015).

\begin{tabular}{lccc}
\hline Clostridia detected by IHC & Number of individual cases (\%) & Number of association cases (\%) & Total (\%) \\
\hline C. chauvoei & $10(27.0)$ & $16(43.2)$ & $26(70.3)$ \\
C. perfringens type A & $6(16.2)$ & $11(29.7)$ & $17(45.9)$ \\
C. septicum & $1(2.7)$ & $12(32.4)$ & $13(35.1)$ \\
C. novyi & $1(2.7)$ & $4(8.1)$ & $4(10.8)$ \\
C. sordellii & $0(0.0)$ & $4(10.8)$ & $4(10.8)$ \\
\hline
\end{tabular}

studies aimed to evaluate the etiological diagnosis of clostridial myonecrosis in ruminants, and $\boldsymbol{C}$. perfringensis rarely included among the pathogens tested (ASSIS et al., 2010). In our retrospective study, this agent was detected in $45.9 \%$ of the cases. Among the seven outbreaks included in the present study, $\boldsymbol{C}$. perfringens was detected in five (71.4\%). Clostridium perfringens type $\mathrm{A}$ is commonly recognized as an enteric pathogen of several animal species (SILVA \& LOBATO, 2015).As an etiological agent of gas gangrene, this bacteria seems to be more prevalent in humans than in animals (STEVENS et al., 2012; UZAL et al., 2016). Although $\boldsymbol{C}$. perfringens has been described in avian species as a cause of dermatitis (CLARK et al., 2010) and eventually causing gas gangrene in some animal species including elephants (RAHMAN et al., 2009), horses (PEEK et al., 2003), dogs (SEDIGH et al., 2015) and primates (YASUDA et al., 2015), this agent is rarely reported in cattle and other domestic ruminants (PACHECO et al., 2008; UZAL et al., 2016).

The high frequency of $\boldsymbol{C}$. perfringens type A detection suggests that this agent should be part of the routine clostridial vaccines. Reversed genetics have demonstrated that alpha toxin is the main virulence factor for $\boldsymbol{C}$. perfringens type A causing gas gangrene and that vaccination with alpha toxoid could protect animals against malignant edema by this agent (WARD et al., 1995).Conversely, while C. septicum, $C$. chauvoei, $C$. sordellii and $C$. novyi are commonly present in most commercial vaccines in Brazil, very few immunogens include alpha toxoid from $\boldsymbol{C}$. perfringens in their composition. According to the Brazilian National Agricultural Laboratory, 36 different vaccines against clostridial diseases in cattle were commercialized in Brazil during 2015, but only five $(13.9 \%)$ have alpha toxoid in their formula (Personal Communication, George Caldeira - Brazilian Ministry of Agriculture, Livestock and Food Supply). Interestingly, brazilian government systematically evaluates the potency of some clostridial antigens present in these vaccines, including $\boldsymbol{C}$. perfringens epsilon and beta toxoid, C. botulinum types $\mathrm{C}$ and $\mathrm{D}$ toxoids and bacteria of C. chauvoei (BRASIL, 1997). So, even in those few vaccines containing $\boldsymbol{C}$. perfringens alpha toxoid, there is no guarantee that it would be protective.

Information regarding the use of vaccines against clostridial myonecrosis was absent in most cases of the present study, so few can be discussed in this matter. The standard protocol for vaccination against clostridial diseases includes the immunization of ruminants at 3 months of age followed by a booster near 8 months of age. The absence of a booster is a common procedure in Brazilian farms and can severely affect the protection of these animals against blackleg and malignant edema. In the present study, this incorrect vaccination protocol was reported in two outbreaks where 8 and 14 animals were affected by $\boldsymbol{C}$. chauvoei alone and by a mixed infection of $\boldsymbol{C}$. chauvoei and $\boldsymbol{C}$. novyi, respectively.

The present study confirms $\boldsymbol{C}$. chauvoei as the most common agent in clostridial myonecrosis but also suggests that $\boldsymbol{C}$. perfringens is much more common than previously reported. Broader studies are needed to confirm this finding and, if these studies are conducted, the use of vaccines containing alpha toxoid should be stimulated to reduce the losses caused by clostridial myonecrosis in cattle.

\section{ACKNOWLEDGEMENTS}

The authors are thankful for the financial support from Fundação de Amparo à Pesquisa do Estado de Minas Gerais (Fapemig), Coordenação de Aperfeiçoamento de Pessoal de Nível Superior (Capes/Proex) and Conselho Nacional de Desenvolvimento Científico e Tecnológico (CNPq).

\section{REFERENCES}

ASSIS, R.A. et al. Bovine clostridial myonecrosis. Arquivos do Instituto Biológico, v.77, n.2, p.331-334, 2010. Available from: $<$ http://www.biologico.sp.gov.br/docs/arq/v77_2/assis.pdf $>$. Accessed: Sept. 10, 2016. 
BRASIL. Ministério da Agricultura, Pecuária e Abastecimento. Portaria n. 49 de 12 de maio de 1997. Diário Oficial da União, Brasília, 16 de maio de 1997. Seção 1, p.10168-10169.

CASAGRANDE, R.A. et al. Histopathological, immunohistochemical and biomolecular diagnosis of myocarditis due to Clostridium chanvoei in a bovine. Ciência Rural, v.45, n.8, p.1472-1475, 2015. Available from: <http://dx.doi. org/10.1590/0103-8478cr20141447>. Accessed: Sept. 10, 2016. doi: $10.1590 / 0103-8478 \mathrm{cr} 20141447$.

CLARK, S. et al. Clostridial dermatitis and cellulitis: an emerging disease of turkeys. AvianDiseases, v.54, p.788-94, 2010. Available from: <http://www.ncbi.nlm.nih.gov/pubmed/20608520>. Accessed: Sept. 10, 2016.

CORREA, W.M. et al. Enfermidades por clostrídios 1969-78. Arquivo Brasileiro de Medicina Veterinária e Zootecnia, v.32, p.369-74, 1980.

GROSETH, P.K. et al. Large outbreak of blackleg in housed cattle. Veterinary Record, v.24, p.339, 2011. Available from: <http:// www.ncbi.nlm.nih.gov/pubmed/21891785>. Accessed: Sept. 10, 2016. doi: $10.1136 /$ vr.d4628.

HOGG, R. et al. Clostridial myocarditis in a scimitar-horned oryx. Veterinary Record, v.165, p.356, 2009. Available from: $<\mathrm{http}: / / w w w$. ncbi.nlm.nih.gov/pubmed/19767644>. Accessed: Sept. 10, 2016.

LIMA, C.G.R.D. et al. Outbreak of gas gangrene in a flock of sheeps and goats. Ciência Veterinária dos Trópicos, v.9, p.10609, 2006. Available from: <http://www.rcvt.org.br/volume9-2-3/ relato3.pdf>. Accessed: Sept. 10, 2016.

LOBATO, F.C.F. et al. Clostridial infection in farm animals. Veterinária e Zootecnia, v.20, p.29-48, 2013. Available from: $<$ http://www.fmvz.unesp.br/rvz/index.php/rvz/article/view/651>. Accessed: Sept. 10, 2016.

MACÊDO, J.T.S.A. et al. Malignant edema caused by Clostridium chauvoei in a horse. Acta Scientiae Veterinariae, v.41, p.24 2013. Available from: <http://www.ufrgs.br/actavet/41-suple-1/ CR 24.pdf>. Accessed: Sept. 10, 2016.

NAGANO, N. et al. Human fulminant gas gangrene caused by Clostridium chauvoei. Journal of Clinical Microbiology, v.46, p.1545-1547, 2008. Available from: <http://www.ncbi.nlm.nih. gov/pmc/articles/PMC2292918/>. Accessed: Sept. 10, 2016. doi: 10.1128/JCM.01895-07.

PACHECO, J.C.G. et al. Gaseous gangrene by Clostridium perfringens type A in vaccinated bull - Case Report. Ensaios e Ciência: Ciências biológicas, Agrárias e da Saúde, v.12, n.1, p.181-186, 2008.

PEEK, S.F. et al. Clostridial myonecrosis in horses ( 37 cases 1985 2000). Equine Veterinary Journal, v.35, n. 1, p.86-92, 2003. Available from: <http://www.ncbi.nlm.nih.gov/pubmed/12553469>. Accessed: Sept. 10, 2016. doi: 10.2746/042516403775467513.
PIRES, P.S. et al. Comparative analysis of lesions caused by histotoxic clostridia in experimentally induced myonecrosis. Semina: Ciências Agrárias, v.33, p.23372346, 2012. Available from: <http://dx.doi.org/10.5433/16790359.2012v33n6p2337>. Accessed: Sept. 10, 2016. doi: 10.5433/1679-0359.2012v33n6p2337.

RAHMAN, H. et al. Clostridial myonecrosis clinically resembling black quarter in an Indian elephant (Elephas maximus). Revue Scientifique et Techinique, v.28, p.1069-75, 2009. Available from: $<$ http://www.ncbi.nlm.nih.gov/pubmed/20462165>. Accessed: Sept. 10, 2016.

RAMOS-VARA, J.A. et al. Suggest guidelines for immunohistochemical techniques in veterinary diagnostic laboratories. Journal of Veterinary Diagnostic Investigation, v.20, p.393-413, 2008. Available from: <http://www.ncbi.nlm. nih.gov/pubmed/18599844>. Accessed: Sept. 10, 2016. doi: $10.1177 / 104063870802000401$.

SEDIGH, H.S. et al. An unusual necrotic myositis by Clostridium perfringens in a German Shepherd dog: aclinical report, bacteriological and molecular identification.Veterinary Research Forum, v.6, p.349-353, 2015. Available from: <http://www.ncbi. nlm.nih.gov/pubmed/26973773>. Accessed: Sept. 10, 2016.

SILVA, R.O.S.; LOBATO, F.C.F. Clostridium perfringens: a review of enteric diseases in dogs, cats and wild animals. Anaerobe, v.33, p.14-17, 2015. Available from: $<\mathrm{http}: / / \mathrm{www}$. ncbi. nlm.nih.gov/pubmed/25644183>. Accessed: Sept. 10, 2016. doi: 10.1016/j.anaerobe.2015.01.006.

STEVENS, D.L. et al. Life-threatening clostridial infections. Anaerobe, v.18, p.254-259, 2012. Available from: <http://www. ncbi.nlm.nih.gov/pubmed/22120198>. Accessed: Sept. 10, 2016. doi: 10.1016/j.anaerobe.2011.11.001.

UZAL, F.A. et al. Gas gangrene (malignant edema), In: Clostridial diseases of animals. Hoboken, NJ: John Wiley \& Sons, 2016.p.243-254. Available from: <http://www.wiley.com/ WileyCDA/WileyTitle/productCd-1118728408.html>. Accessed: Sept. 10, 2016.

UZAL, F.A. et al. Outbreak of clostridial myocarditis in calves. Veterinary Record, v.54, p.134-136, 2003a. Available from: $<$ http://www.ncbi.nlm.nih.gov/pubmed/12585599>. Accessed: Sept. 10, 2016.

UZAL, F.A. et al. PCR detection of Clostridium chauvoei in pure cultures and in formalin-fixed, paraffin-embedded tissues. Veterinary Microbiology, v.91, p.239-248, 2003b. Available from: $<$ http://www.ncbi.nlm.nih.gov/pubmed/12458172>. Accessed: Sept. 10, 2016. doi: 10.1016/S0378-1135(02)00291-2.

WILLIAMS, B.M. Clostridial myositis in cattle: bacteriology and gross pathology. Veterinary Record, v.100, p.90-91, 1977. Available from: <http://www.ncbi.nlm.nih.gov/pubmed/190758>. Accessed: Sept. 10, 2016. 